\title{
Karakteristik Pola Pertumbuhan dan Distribusi Ukuran Thunnus albacares, Bonnaterre, 1788 (Teleostei: Scombridae) yang Tertangkap dengan Pancing Ulur di Perairan Selatan Pulau Ambon
}

\author{
Jacobus Bunga Paillin*, Stany Rachel Siahainenia, Ruslan Husen Saban Tawari \\ Jurusan Pemanfaatan Sumberdaya Perikanan, Fakultas Perikanan dan IImu Kelautan, \\ Universitas Pattimura \\ Jl. Mr. Chr. Soplanit Kampus Poka, Ambon Maluku 97234 Indonesia \\ Email: bobby.b.paillin@gmail.com
}

\begin{abstract}
Characteristics of growth patterns and size distribution of Thunnus albacares Bonnaterre, 1788 (Teleostei: Scombridae) caught by hand line in the Southern Waters of Ambon Island
\end{abstract}

Handline is a fishing tool that is always used by fishermen in Passo Village to catch tuna fish in the southern waters of Ambon Island. In carrying out tuna fishing activities, these fishermen use two hand lines at the same time operating together but differ in their operating techniques. This research was conducted to know the size distribution and growth pattern of yellowfin tuna caught by handline (PUT and PUH) in the southern waters of Ambon Island. From the results of this study, the total yellowfin tuna caught using the PUT handline was 323 individuals with an average class length of $117.23 \mathrm{~cm}$, while the yellowfin tuna caught using the PUH handline was 159 with an average class length of $118.1 \mathrm{~cm}$. The average total weight of yellowfin tuna caught by the PUT handline was $21.26 \mathrm{~kg}$. The average total weight caught using the PUH handline was $21.94 \mathrm{~kg}$. The growth pattern of yellowfin tuna as a whole is negative allometric, which means that the length growth is faster than the weight growth.

Keywords: Handline, Yellowfin tuna, Size distribution, Growth pattern, Ambon island

\begin{abstract}
Abstrak
Pancing ulur merupakan alat tangkap yang selalu dipakai oleh nelayan di Desa Passo untuk menangkap ikan tuna di perairan selatan Pulau Ambon. Dalam melakukan aktivitas penangkapan ikan tuna, nelayan tersebut menggunakan dua pancing ulur (hand line) sekaligus diopresikan secara bersama-sama namun berbeda dalam teknik pengoprasiannya. Penelitian ini dilakukan dengan tujuan untuk mengetahui distribusi ukuran dan pola pertumbuhan ikan tuna madidihang yang tertangkap dengan pancing ulur (PUT dan PUH) di perairan selatan Pulau Ambon. Dari hasil penelitian ini total ikan tuna madidihang yang tertangkap dengan PUT sebanyak 323 individu dengan rata-rata kelas ukuran panjang yang tertangkap yaitu $117.23 \mathrm{~cm}$, sedangkan tuna madidihang yang tertangkap menggunakan PUH sebanyak 159 ekor dengan rata-rata kelas Ukuran panjang $118.1 \mathrm{~cm}$. Rata-rata berat total tuna madidihang yang tertangkap dengan PUT yaitu 21.26 $\mathrm{kg}$. rata-rata berat total yang tertangkap dengan PUH yaitu $21.94 \mathrm{~kg}$. Pola pertumbuhan ikan tuna madidihang secara keseluruhan bersifat allometrik negatif hal ini berarti pertumbuhan panjang lebih cepat pertumbuhan beratnya.
\end{abstract}

Kata Kunci: Pancing ulur, Thunnus albacares, distribusi ukuran, Pola pertumbuhan, Pulau Ambon

\section{PENDAHULUAN}

Tuna madidihang (Thunnus albacares) adalah jenis ikan pelagis besar yang tersebar sangat luas dan mendiami seluruh lautan hangat didunia yang meliputi perairan tropis dan sub tropis (Rohita et al., 2012; Diaz dan Uribe, 2003; Ely et al., 2005). Tuna sirip kuning (Thunnus albacares) atau lebih dikenal dengan nama madidihang adalah salah satu 
spesies Family Scombridae dan merupakan salah satu komoditi perikanan yang paling utama di Indonesia selain tuna selain tuna yang lain (Tangke et al., 2011). Madidihang merupakan jenis ikan tuna yang paling dicari didunia karena memiliki nilai ekonomis dan nilai komersil dan selalu diburu oleh nelayan (Paillin et al., 2020; Yosuva et al., 2018; Rohit and Rammohan, 2009). Diaz dan Uribe (2003) mengemukakan spesies ini merupakan penyumbang lebih dari sepertiga tuna produksi tuna di dunia sejak 1970. Mayoritas hasil tangkapan tuna diambil oleh industri yang didapat dari purse seine (60\%), longline (17\%), dan berbagai alat tangkap skala kecil di Philipina dan Timur Indonesia seperti hand line, gill net (20\%).

Secara ekonomis Kandungan protein tuna madidihang pada penelitian di bulan Maret-Mei 2015 rata-rata Berkisar antara 14,3216,41\% (Katun et al., 2015). Penelitian lain juga memperoleh kandungan protein pada bagian daging tuna madidihang dalam keadaan segar sebesar 23,2\% Wahyuni (2011), Peng et al. (2013) memperoleh 23,52 \%, Wellyana et al. (2013) memperoleh 20,64\%, Nurilmala et al. (2006) memperoleh 26,02 \% pada bagian tulang tuna. Secara komersil ekspor tuna di Maluku pada tahun 2018 sebesar 1.144,17 ton dengan nilai ekspor sebesar US\$. 10.890.301 yang mana pemanfaatan tuna madidihang diperairan selatan Pulau Ambon yang merupakan bagian dari Laut Banda turut memberikan kontribusi yang sangat besar terhadap perekonomian Maluku (Haruna et al, 2019.)

Lebih lanjut Ihsan et al. (2017) mengemukakan bahwa selain industri pemanfaatan sumberdaya tuna madidihang juga dilakukan oleh perikanan rakyat dan sudah menjadi suatu mata pencaharian pokok bagi banyak orang. Salah satu perikanan rakyat yang memanfaatkan sumberdaya ikan tuna sebagai mata pencaharian pokok adalah nelayan yang tinggal di Negeri Passo Kota Ambon. Aktivitas penangkapan terhadap sumberdaya ikan tuna oleh nelayan Negeri Passo biasanya dilakukan di peraian bagian selatan Pulau Ambon. Perairan selatan Pulau Ambon yang adalah bagian dari perairan Laut Banda, secara ekologis merupakan daerah migrasi, tempat asuhan, pemangsaan dan pemijahan bagi ikan tuna madidihang (Wagiyo et al., 2015). Pemanfaatan ikan tuna di perairan ini sangat tinggi di lakukan oleh industri penangkapan maupun oleh nelayan kecil dengan menggunakan berbagai alat tangkap seperti purse seine, pancing tonda, maupun pancing ulur (hand line). Hal ini dapat memberikan dampak terhadap kelangsungan hidup semberdaya ikan tuna khususnya ikan tuna madidihang yang ada di perairan ini.

Pancing ulur (handline) merupakan alat tangkap yang selalu dipakai oleh nelayan Negeri Passo untuk menangkap ikan tuna di perairan selatan Pulau Ambon. Dalam melakukan aktivitas penangkapan ikan tuna, nelayan menggunakan 2 pancing ulur sekaligus yang diopresikan secara bersamasama yang secara konstruksi maupun teknik penghoperasiannya berbeda. Oleh karena itu penelitian dilakukan dengan tujuan untuk mengetahui distribusi ukuran dan pola pertumbuhan ikan tuna madidihang yang tertangkap dengan pancing ulur tangan dan pancing ulur hanyut di perairan selatan Pulau Ambon.

\section{MATERI DAN METODE}

Penelitian ini dilakukan pada bulan Mei - Juli 2019 di perairan selatan Pulau Ambon dengan fishing base di Negeri Passo Kota Ambon (Gambar 1). Pengambilan data dilakukan dengan mengikuti langsung aktivitas penangkapan ikan bersama nelayan dengan menggunakan alat tangkap pancing ulur (hand line) sebanyak 30 trip. Ketika sampai di daerah penangkapan ikan nelayan menurunkan 2 unit pancing ulur (handline sekaligus yaitu pancing ulur tangan (A) dan Pancing ulur hanyut (B). Pancing ulur tangan dioperasikan sebagaimana pancing ulur pada umumnya, sedangkan pancing ulur hanyut dioperasikan dengan cara dibiarkan hanyut bersama penggulungnya. Ikan tuna yang tertangkap di setiap trip penangkapan dari kedua pancing ulur ini dihitung jumlahnya, diukur panjangnya dan ditimbang beratnya. Pengukuran panjang ikan tuna madidihang dapat lihat pada Gambar 2.

\section{Deskripsi Pancing Ulur (PUT)}

Bagian-bagian dari pancing ulur ini yaitu penggulung, tali utama pertama yang 
dihubungkan ke kili-kili I (swivel), kemudian tali utama kedua, kili-kili II (swivel), Tali anak, pemberat yang terbuat dari batu dan mata pancing (Gambar 3.). Proses pemasangan alat (setting) diawali dengan memasang umpan alami dan buatan pada mata pancing menjadi satu kemudian melilitkan tali pancing pada umpan yang sudah dipasang pada mata pancing tersebut dan batu yang berbentuk bulat lonjong atau elips yang berfungsi sebagai pemberat. Pelilitan pada umpan dan pemberat ini menggunakan simpul mudah lepas guna untuk mempermudah pelepasan batu pada kedalaman tertentu dimana ikan berada. Setelah pada kedalaman tertentu dimana ikan berada nelayan melakukan sentakan pada tali pancing agar pemberat berupa batu tersebut lepas dari simpul yang di lilitkan tersebut dan menunggu sambaran ikan pada umpan yang sudah terpasang pada mata pancing tersebut.

\section{Pancing Ulur (PUH)}

Bagian-bagian dari pancing ulur ini antara lain: Penggulung, tali utama yang dihubungkan ke kili-kili I (swivel), kemudian

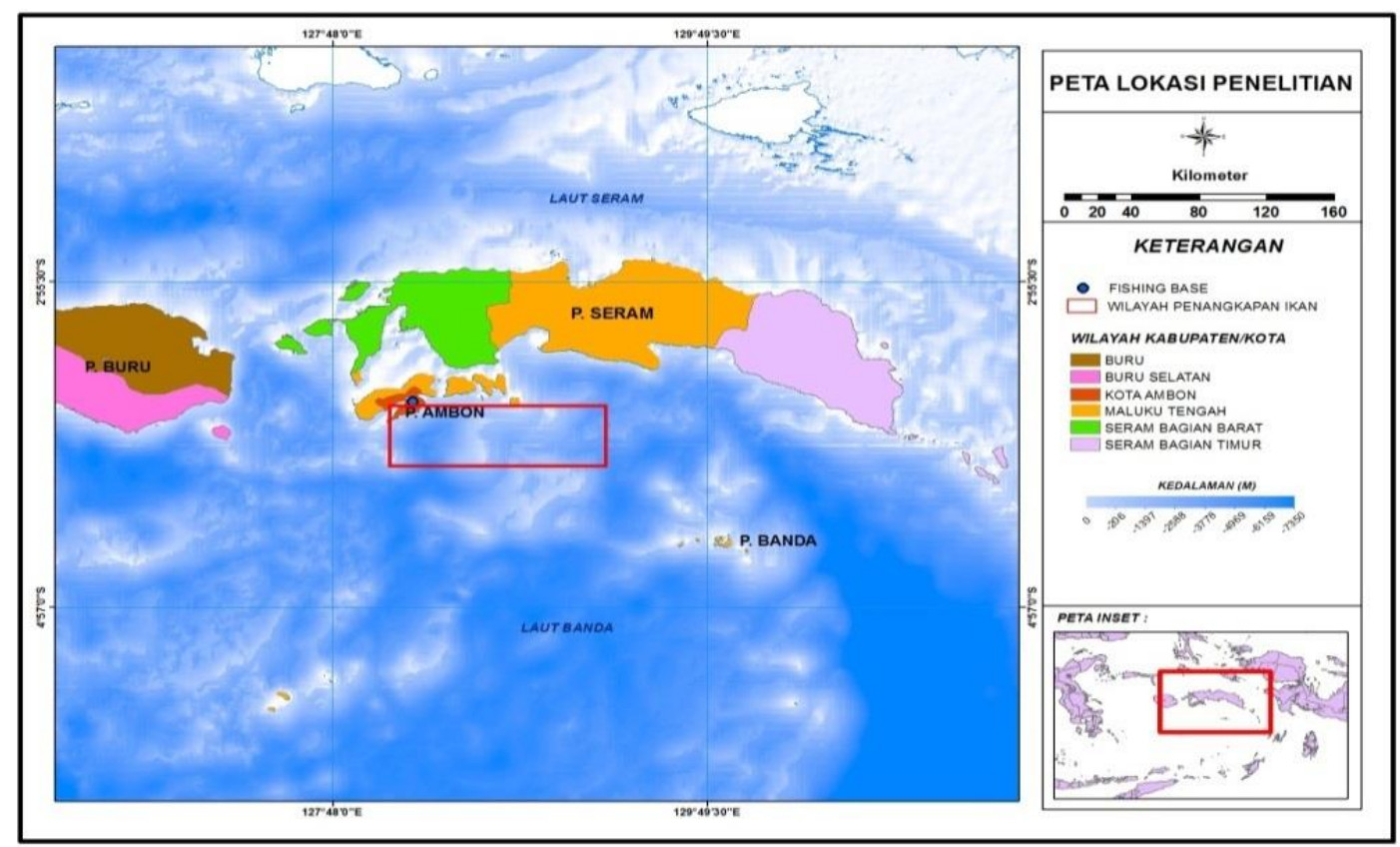

Gambar 1. Peta Lokasi Penelitian

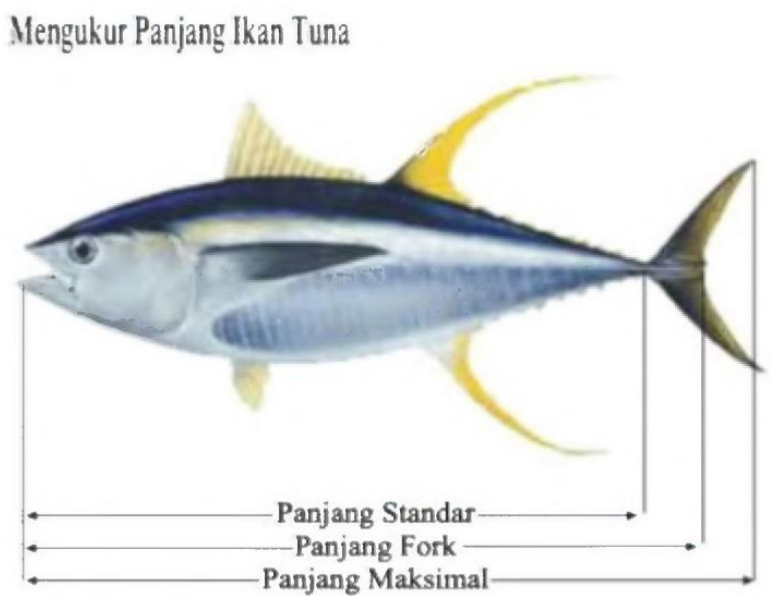

Gambar 2. Pengukuran panjang Ikan Tuna Madidihang 


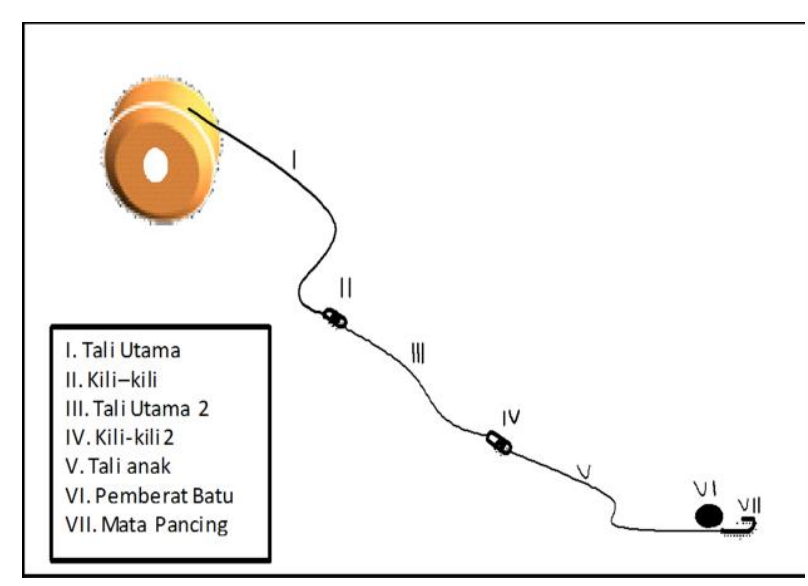

Konstruksi Pancing Ulur (PUT)

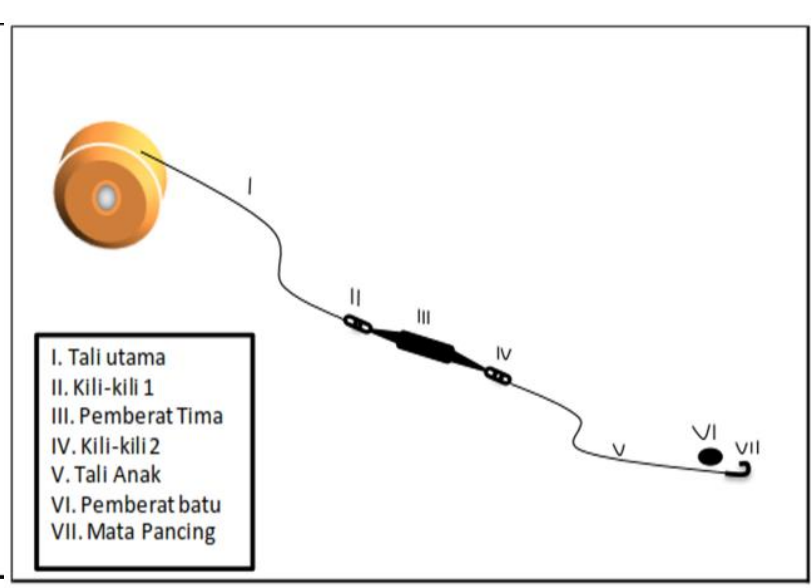

Konstruksi Pancing Ulur (PUH)

Gambar 3. Konstruksi Pancing

pemberat dari timah, kili-kili Il (swivel), tali anak, pemberat dari batu dan mata pancing. Proses pemasangan alat (setting) PUH mirip dengan PUT, namun cara pengoperasiannya berbeda. Pada proses pemasangan umpan alami dan umpan buatan pada mata pancing menjadi satu kemudian melilitkan umpan pada batu yang berbentuk bulat lonjong atau elips yang berfungsi sebagai pemberat tambahan pada PUH. Lilitan yang digunakan sama halnya dengan pancing ulur tangan dengan menggunakan simpul mudah lepas guna untuk mempermudah pelepasan batu pada kedalaman tertentu. Setelah pada kedalaman tertentu nelayan melakukan sentakan pada tali pancing agar pemberat yang berupa batu tersebut terlepas dari simpul yang sudah dililitkan. Setelah itu nelayan membuat simpul lepas juga pada tali pancing dan rol penggulung sehingga mempermudah simpul tersebut lepas pada saat ikan menyambar umpan. satu set $\mathrm{PUH}$ dilemparkan dengan jarak 10-20 meter dari kapal. Saat ikan menyambar umpan, ikan melakukan tekanan pada joran sehingga simpul yang sudah dibuat tersebut lepas dari joran dan joran terangkat 1-5 meter diatas permukaan air.

\section{Analisa Data}

Distribusi kelas ukuran panjang total dan berat total ikan tuna madidihang di analisis secara deskriftif yang disajikan dalam bentuk grafik. Analisis ini untuk menggambarkan ukuran ikan tuna yang paling banyak tertangkap dengan alat tangkap pancing ulur tangan dan hanyut kemudian dibandingkan dengan dengan ukuran ikan tuna madidihang yang pertama kali memijah berdasarkan studi pustaka dari jurnal-jurnal penelitian yang terkait. Analisa distribusi ukuran panjang dan berat tuna madidihang menggunakan persamaan Sturgess (1982). Hasil analisis kemudian diolah menggunakan program minitab 16. Pola pertumbuhan berdasarkan hubungan panjang total dan berat total ikan tuna madidihang dianalisis menggunakan formula Effendie (2002). Pola pertumbuhan ikan tuna madidihang yang diamati digunakan nilai $b$ dengan kriteria sebagai berikut: Jika $b=3$, pola pertumbuhan bersifat isometric, yakni pertambahan panjang sama dengan pertambahan berat; Jika $b>3$, pola pertumbuhan bersifat allometrik positif, yakni pertambahan berat lebih besar dari pertambahan Panjang; Jika $b<3$, pola pertumbuhan bersifat allometrik negative, yakni pertambahan panajang lebih besar dari pertambahan berat.

\section{HASIL DAN PEMBAHASAN}

Distribusi ukuran panjang total ikan tuna madidihang yang tertangkap pada PUT dan PUH bervariasi dan memperlihatkan Ukuran relatif sama untuk kedua pancing ulur (Gambar 4). Ikan tuna madidihang yang tertangkap dengan menggunakan PUT memiliki kisaran panjang antara $45-165 \mathrm{~cm}$. Total keseluruhan ikan tuna madidihang yang 
tertangkap dengan PUT sebanyak 323 ekor dengan rata-rata kelas ukuran panjang yang tertangkap yaitu $117,23 \mathrm{~cm}$ dengan standar deviasi 19,05. Kelas ukuran panjang total yang paling banyak tertangkap yaitu antara 105-124 cm dengan jumlah 177 ekor.

Total Ikan tuna yang tertangkap dengan PUH sebanyak 159 ekor pada kisaran ukuran panjang antara $65-165 \mathrm{~cm}$ dengan rata-rata kelas ukuran panjang yang tertangkap yaitu $118,1 \mathrm{~cm}$ dengan standar deviasi 19.07. Kelas ukuran panjang yang paling banyak atau dominan tertangkap dengan pada PUH yaitu antara 105-124 cm dengan jumlah 78 ekor. Untuk lebih jelasnya dapat dilihat pada Tabel 1.

Tabel 1. Hasil analisa distribusi ukuran panjang total ikan Tuna Madidihang

\begin{tabular}{lcc}
\hline & PUT (A) & PUH (B) \\
\hline Jumlah Sampel (N) & 323 & 159 \\
Mean & 117.2 & 118.1 \\
Standar deviasi & 19.05 & 19.07 \\
\hline
\end{tabular}

Distribusi ukuran panjang ikan sangat penting diketahui, karena tingkat kedewasan ikan dapat ditentukan. Hasil analisis menunjukan bahwa ikan tuna madidihang yang dominan tertangkap pada PUT dan PUH di perairan selatan Pulau Ambon memiliki ukuran panjang $\geq 100 \mathrm{~cm}$. Menurut Sun et al., (2006) dalam Faizah dan Aisyah (2011) ikan tuna yang dianggap dewasa adalah ketika memiliki ukuran panjang 91-100 cm. FAO (2016) menyatakan ikan tuna madidihang pertama kali matang gonad memiliki panjang $100 \mathrm{~cm}$. Selanjutnya Nugroho et al (2018) menyatakan bahwa ikan tuna madidihang yang pertama kali matang gonad atau dikatakan layak tangkap karena diduga telah melakukan pemijahan sebelum ditangkap.

Berdasarkan hasil penelitian sebelumnya diketahui ikan tuna madidihang yang tertangkap di perairan Laut Banda berkisar antara 55-215 cm (Damora \& Baihai, 2013), di perairan Majene dan Makassar berkisar antara 25-180 cm (Kantun et al., 2014), di perairan Samudra Hindia ikan tuna madidihang yang tertangkap pada kisaran ukuran $70-80 \mathrm{~cm}$ (Anggarini et al., 2016), sedangkan Wujdi et al (2015) yang melakukan penelitian di perairan Samudra Hindia bagian timur memperoleh kisaran ukuran panjang ikan tuna madidihang yang tertangkap antara $30-179 \mathrm{~cm}$.

Gambar 5. memperlihatkan kisaran berat total ikan tuna yang tertangkap dengan PUT (A) dan PUH (B). Kisaran Berat total ikan tuna yang tertangkap dengan PUT yaitu antara 1,5-60,4 kg dari 323 ekor yang tertangkap dengan berat rata-rata $21,26 \mathrm{~kg}$ dengan standard deviasi 9,07 . Kisaran berat total yang dominan tertangkap yaitu antara 19-27 kg sebanyak 231 ekor. Untuk alat tangkap PUH ikan tuna yang tertangkap berada pada kisaran berat 3,9-62,7 kg dari 159 ekor dengan rata-rata berat $21,94 \mathrm{~kg}$ dengan standar deviasi 10,02 (Tabel. 2). Kisaran ukuran berat total yang dominan tertangkap dengan PUH antara 19-27 kg sebanyak 105 ekor.

Tabel 2. Hasil analisa distribusi ukuran berat total ikan Tuna Madidihang

\begin{tabular}{lcc}
\hline & PUT & PUH \\
\hline Jumlah Sampel (N) & 323 & 159 \\
Mean & 21.26 & 21.94 \\
Standar deviasi & 9.07 & 10.02 \\
\hline
\end{tabular}

Dominasi rata-rata berat ikan tuna madidihang yang tertangkap mengunakan PUT dan PUH $\geq 20 \mathrm{~kg}$. Ukuran tersebut merupakan ukuran berat tuna madidihang ketika pertama kali matang gonad (Ihsan et al., 2017). Dengan demikian dapat dikatakan bahwa rata-rata ikan tuna madidihang yang tertangkap dengan PUT dan PUH merupakan ikan yang layak tangkap karena diduga telah memijahan sebelum ditangkap

\section{Pola Pertumbuhan}

Hasil analisis pola pertumbuhan berdasarkan hubungan panjang dan berat total ikan tuna madidihang yang tertangkat di perairan selatan Pulau Ambon dapat dilihat pada Gambar 6. Dari analisis tersebut diperoleh persamaan $y=0.0225 x^{2.8746}$ dengan nilai koefisien korelasi ( $r$ ) sebesar 0.96 yang berarti bahwa hubungan antara panjang total dengan berat sangat mempengaruhi karena berada pada kisaran 96-99\% atau mendekati 1, nilai konstanta (b) sebesar 2,8746 
yang berarti bahwa pola pertumbuhan ikan tuna madidihang adalah bersifat allomatrik negatif atau pertumbuhan panjang lebih cepat pertumbuhan beratnya.

Pola pertumbuhan allomatrik negatif tuna madidihang yang tertangkap di perairan selatan Pulau Ambon ini sama dengan pola pertumbuhan ikan tuna madidihang yang tertangkap diperairan Samudera Hindia (Hartaty dan Sulistyaningsih, 2011) di perairan Samudera Hindia bagian timur (Nugroho et al., 2018), diperairan Bitung (Darondo et al., 2020), diperairan parangipettai tenggara india (Yosuva et al., 2018). Penelitian yang di

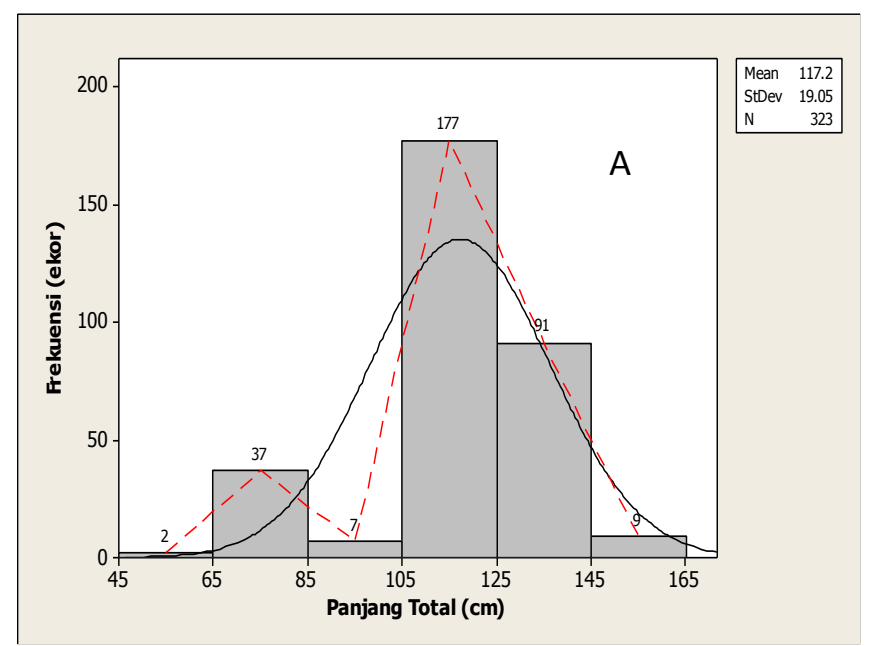

lakukan oleh Zhu et al (2008) di perairan atlantik, india dan pasifik timur mendapatkan pola pertumbuhan dari tuna madidihang adalah isometrik.

Menurut Zakeyudin, (2012) pertumbuhan panjang dan berat ikan pada suatu perairan sangat dipengaruhi oleh faktor lingkungan perairan di antaranya ketersediaan dan ukuran makanan yang dimakan, kelimpahan ikan sebagai makanan di perairan tersebut, jenis makanan, kondisi oseanografi perairan seperti: suhu, oksigen terlarut, jenis kelamin dan umur ikan.

Gambar 4. Distribusi Ukuran Panjang Total Ikan Tuna Madidihang Yang Tertangkap Dengan PUT (A) dan PUH (B)
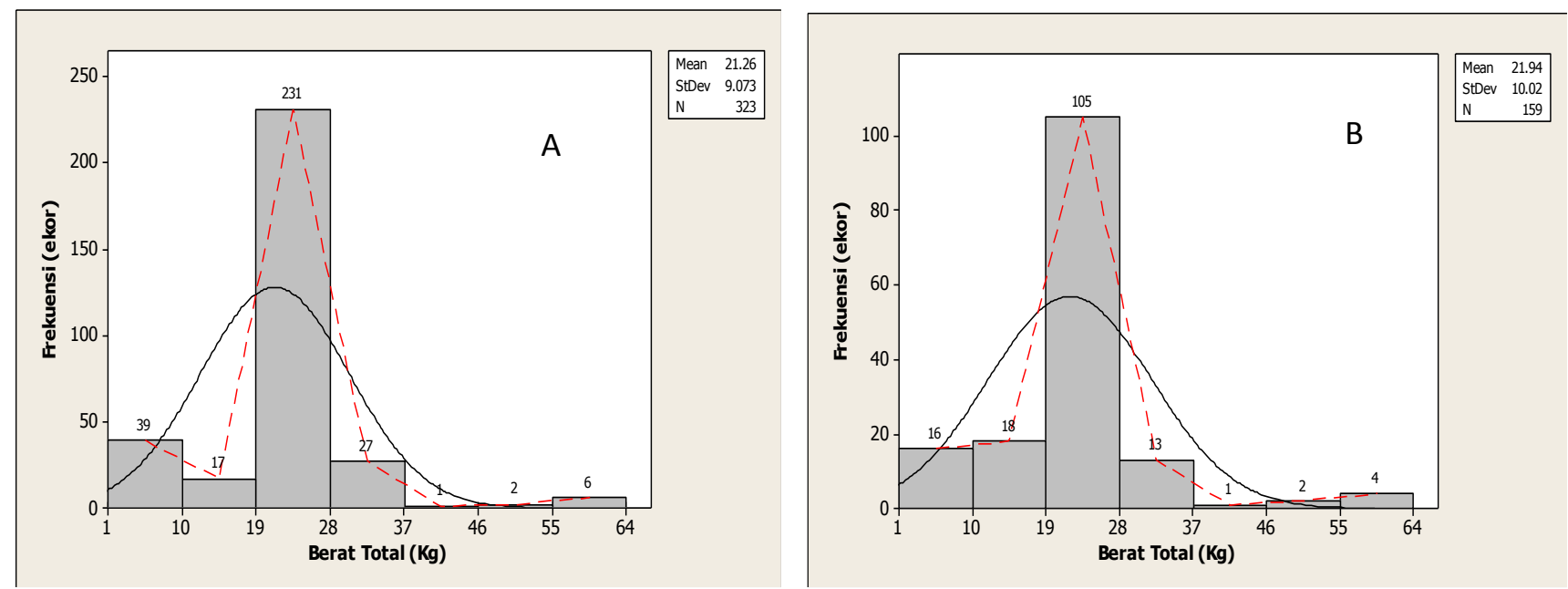

Gambar 5. Distribusi Ukuran Berat Total Ikan Tuna Madidihang Yang Tertangkap Dengan PUT (A) dan PUH (B) 


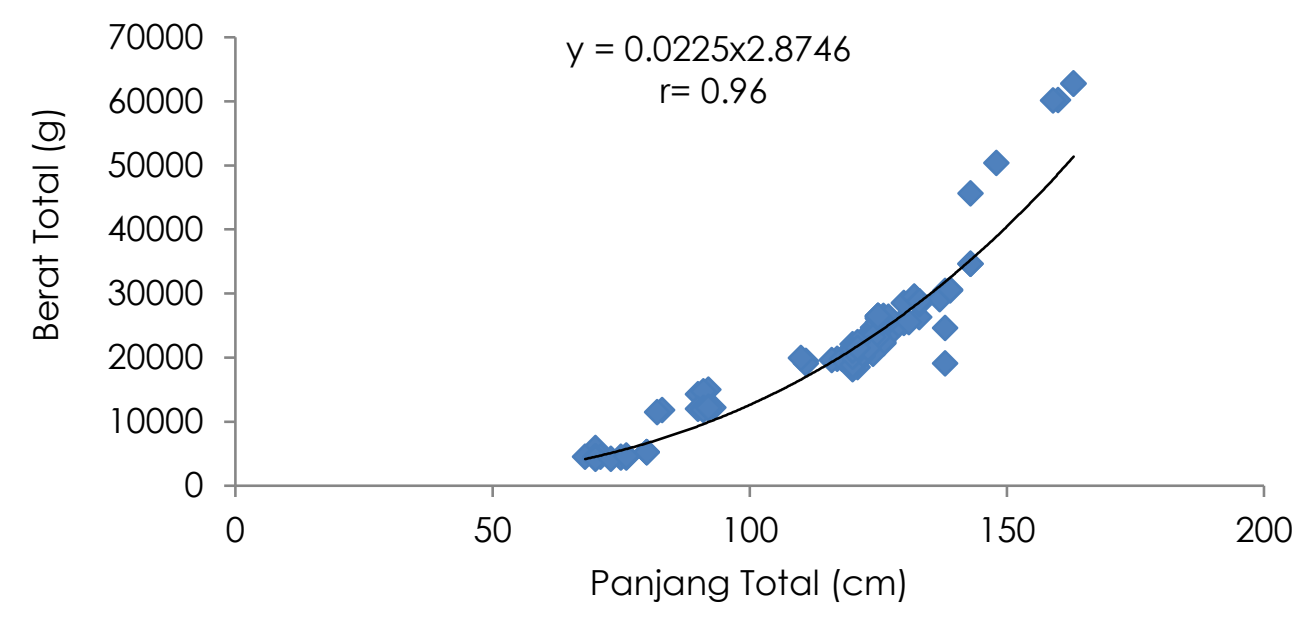

Gambar 6. Hubungan Panjang-Berat Ikan Tuna Madidihang

\section{KESIMPULAN}

Ikan tuna madidihang yang tertangkap di perairan selatan Pulau Ambon dengan pancing ulur (PUT dan PUH) merupakan ikan layak tangkap dengan sebaran ukuran panjang rata-rata $117,23 \mathrm{~cm}$ dan berat ratarata $21,26 \mathrm{~kg}$ untuk PUT, sedangkan PUH ratarata kelas ukuran panjang yang tertangkap adalah $118,13 \mathrm{~cm}$ dan berat $21,94 \mathrm{~kg}$. Pola pertumbuhan ikan tuna madidihang yang tertangkap di perairan selatan Pulau Ambon bersifat allomatrik negatif

\section{DAFTAR PUSTAKA}

Damora, A., \& Baihaqi, B. 2013. Struktur ukuran ikan dan parameter populasi madidihang (Thunnus albacares) di perairan Laut Banda. BAWAL Widya Riset Perikanan Tangkap, 5(1):59-65. doi : 10.15578/baw al. 5.1.2013.59-65

Darondo, F.A., Halim, S., Jabbar, M.A., \& Wudianto. 2020. Struktur Ukuran, Pola Pertumbuhan Dan Rata-rata Panjang Pertama Kali tertangkap ikan Madidihang (Thunnus albacares) di Perairan Bitung. Jurnal IImu dan Teknologi Perikanan Tangkap. 5(1):7-17. doi : 10.35800/jitpt.5.1. 2020.28048

Díaz-Jaimes, P., \& Uribe-Alcocer, M. 2003. Allozyme and RAPD variation in the eastern Pacific yellowfin tuna (Thunnus albacares). Fishery Bulletin, 101 (4):769-777
Effendie. 2002. Biologi Perikanan. Yayasan Pustaka Nusantara, Yogyakarta, $163 \mathrm{hlm}$.

Ely, B., Viñas, J., Alvarado Bremer, J. R., Black, D., Lucas, L., Covello, K., Labrie, A.V., \& Thelen, E. 2005. Consequences of the historical demography on the global population structure of two highly migratory cosmopolitan marine fishes: The yellowfin tuna (Thunnus albacares) and the skipjack tuna (Katsuwonus pelamis). BMC Evolutionary Biology, 5:1-9. doi : 10.1186/1471-2148-5-19

Faizah, R., \& Aisyah. 2011 . Komposisi Jenis dan Distribusi Ukuran Ikan Pelagis Besar Hasil Tangkapan Pancing Ulur di Sendang Biru, Jawa Timur. Bawal, 3(6):377-385.

FAO. 2016, Biological Characteritics of Tuna (online). http://www.fao.org/fishery/top ic/16082/en

Hampton, J., \& Fournier, D.A. 2001. A spatially disaggregated, length-based, agestructured population model of yellowfin tuna (Thunnus albacares) in the western and central pacific ocean. Marine and Freshwater Research, 52(7):937-963. doi : 10.1071/MF01049

Hartaty, H., \& Sulistyaningsih, K. 2014. Pendugaan Parameter Populasi dan tingkat Pemanfaatan Ikan Madidihang (Thunnus albacares) yang Didaratkan di Benoa, Bali. Jurnal Penelitian Perikanan Indonesia, 20(2):97-103.

Haruna., Paillin, J.B., Tawari, R.H.S., Tupamahu, A., Siahainenia, S.R. \& Silooy, F.D. 2019. Dinamika Daerah Penangkapan Tuna 
Madidihang (Thunnus albacares) Di Perairan Laut Banda. Prosiding Pertemuan IImiah Nasional Tahunan XVI ISOI 2019. November, 7-8.

Ihsan, M., Yusfiandayani, R., Baskoro, M.S., \& Mawardi, W. 2017. Hasil Tangkapan Ikan Madidihang Dari Aspek Teknis Dan Biologi Menggunakan Armada Pancing Tonda Di Perairan Palabuhanratu. Jurnal Teknologi Perikanan Dan Kelautan, 8(1):115-123.

Kantun, W., Mallawa, A. \& Rapi, N.L., 2014. Structure Size and Number of Catches According from Yellow fin (Thunnus albacares) to Time and Depth in Makassar Strait. Jurnal Saintek Perikanan, 9(2):39-48. doi: 10.14710/ijfst.9.2.39-48

Kantun, W., Malik, A.A., \& Hariyanti. 2015. Kelayakan Limbah Padat Tuna Loin Madidihang Thunnus albacares Untuk Bahan Baku Produk di Verifikasi. Jurnal Pengolahan Hasil Perikanan Indonesia, 18(3):303-314. doi : 10.17844/jphpi.2015. 18.3.303

Nurilmala, M., Wahyuni, M. \& Wiratmaja, H. 2006. Perbaikan nilai tambah limbah tulang ikan tuna (Thunnus sp.) menjadi gelatin serta analisis fisika-kimia. Buletin Teknologi Hasil Perikanan. 9(2):22-31.

Paillin, J.B., Matrutty, D.D.P., Siahainenia, S.R., Tawari, R.H.S., Haruna, H., \& Talahatu, P. 2020. Daerah Penangkapan Potensial Tuna Madidihang Thunnus albacares, Bonnaterre, 1788 (Teleostei:Scombridae) di Laut Seram. Jurnal Kelautan Tropis, 23(2):207-216. doi: 10.14710/jkt.v23i2.7073

Peng, S., Chen, C., Shi, Z., \& Wang, L. 2013. Amino Acid and Fatty Acid Composition of the Muscle Tissue of Yellowfin Tuna (Thunnus Albacares) and Bigeye Tuna (Thunnus Obesus). Journal of Food and Nutrition Research, 1 (4):42-45. doi : 10.126 91/jfnr-1-4-2

Rohit, P., \& Rammohan, K. 2009. Fishery and biological aspects of Yellowfin tuna Thunnus Albacares along Andhra coast, India. Asian Fisheries Science, 22(1):235244.

Rohit, P., Rao, G.S., \& Rammohan, K. 2012. Age, growth and population structure of the yellowfin tuna Thunnus albacares (Bonnaterre, 1788) exploited along the east coast of India. Indian Journal of Fisheries, 59(1):1-6.
Tangke, U., Mallawa, A., \& Zainuddin, M. 2011. Analisis hubungan karakteristik oseanografi dan hasil tangkapan yellowfin tuna (Thunnus albacares) di perairan Laut Banda. Agrikan: Jurnal Ilmiah Agribisnis Dan Perikanan, 4(2):1-14. doi : 10.29239/ j.agrikan.4.2.1-14

Wagiyo, K., Suman, A., \& Patria, M.P. 2015. Sebaran dan Hubungan Parameter Reproduksi Ikan Tuna Madidihang (Thunnus albacares) Dengan Suhu Dan Klorofil-A Di Laut Banda. Bawal : Widya Riset Perikanan Tangkap, 7(3):183-191. doi : 10.15578/bawal.7.3.2015.183-191

Wahyuni S. 2011. Histamin Tuna (Thunnus sp.) dan identifikasi bakteri pembentuknya pada kondisi suhu penyimpanan standard. [Skripsi]. Bogor: Teknologi Hasi Perikanan IPB.

Wellyalina, Azima, F. \& Aisman. 2013. Pengaruh perbandingan tetelan tuna dan tepung maizena terhadap mutu nugget. Jurnal Aplikasi Teknologi Pangan 2(1):9-17.

Wujdi, A., Setyadji, B. \& Nugraha, B. 2015. Sebaran Ukuran panjang dan nisbah kelamin ikan madidihang (Thunnus albacares) di Samudra Hindia bagian timur. Bawal : Widya Riset Perikanan Tangkap, 7(3):175-182

Yosuva, M., Jeyapragash, D., Manigandan, V., Machendiranathan, M. \& Saravanakumar, A. 2018. Length-weight relationship and relative condition factor of yellowfin tuna (Thunnus albacares) from Parangipettai coast, southeast coast of India. Zoology and Ecology, 28(2):94-99. doi : 10.1080/ 21658005. 2018.1455319

Zakeyudin, M., Isa, M.M., Rawi, C.M., Shah, A.S.M., \& Ahmad, A.H. 2012. Assessment of Suitability of Kerian River Tributaries Using Length-weight Relationship and Relative Condition Factor of Six Freshwater Fish Species. Journal of Environment and Earth Science, 2(3):52-61.

Zhu, G., Xu, L., Zhou, Y., \& Dai, X. 2008. Lengthfrequency compositions and weightlength relations for big-eye tuna, yellowfin tuna, and albacore (Perciformes: Scombrinae) in the Atlantic, Indian, and eastern Pacific oceans. Acta Ichthyologica et Piscatoria, 38(2):157-161. doi : 10.3750/ AIP2008.38.2.12 